University of Nebraska - Lincoln

DigitalCommons@University of Nebraska - Lincoln

USGS Staff -- Published Research

US Geological Survey

1990

\title{
Paleoclimatic implications of the high stand of Lake Lahontan derived from models of evaporation and lake level
}

$S$ Hostetler

US Geological Survey

Larry Benson

University of Colorado at Boulder, great.basin666@gmail.com

Follow this and additional works at: http:// digitalcommons.unl.edu/usgsstaffpub

Hostetler, S and Benson, Larry, "Paleoclimatic implications of the high stand of Lake Lahontan derived from models of evaporation and lake level" (1990). USGS Staff-- Published Research. 790.

http:// digitalcommons.unl.edu/usgsstaffpub/790

This Article is brought to you for free and open access by the US Geological Survey at DigitalCommons@University of Nebraska - Lincoln. It has been accepted for inclusion in USGS Staff -- Published Research by an authorized administrator of DigitalCommons@University of Nebraska - Lincoln. 


\title{
Paleoclimatic implications of the high stand of Lake Lahontan derived from models of evaporation and lake level
}

\author{
S Hostetler and LV Benson \\ US Geological Survey, National Center for Atmospheric Research, P.O. Box 3000ML, Boulder, Co 80301-3000, USA \\ Received December 4, 1989/Accepted May 7, 1990
}

\begin{abstract}
Based on previous climate model simulations of a split of the polar jet stream during the late Pleistocene, we hypothesize that (1) 20-13.5 ka BP, season-toseason variation in the latitudinal maximum of the jet stream core led to enhanced wetness in the Great Basin, and (2) after $13.5 \mathrm{ka} \mathrm{BP}$, northward movement of the jet stream resulted in increased aridity similar to today. We suggest that the enhanced effective wetness was due to increased precipitation combined with an energylimited reduction in evaporation rates that was caused by increased summer cloud cover. A physically based thermal evaporation model was used to simulate evaporation for Lake Lahontan under various hypothesized paleoclimates. The simulated evaporation rates, together with hypothetical rates of precipitation and discharge, were input to a water balance model of Lake Lahontan. A $42 \%$ reduction in evaporation rate, combined with maximum historical rates of precipitation (1.8 times the mean annual rate) and discharge (2.4 times the mean annual rate), were sufficient to maintain Lake Lahontan at its $20-15 \mathrm{ka}$ BP level. When discharge was increased to 3.8 times the present-day, mean annual rate, the $\sim 13.5 \mathrm{ka}$ BP maximum level of Lake Lahontan was attained within 1400 years. A 135 -m drop from the maximum level to Holocene levels was simulated within 300 years under the imposition of the present-day hydrologic balance.
\end{abstract}

\section{Introduction}

Atmospheric general circulation models (AGCMs) have been used to simulate synoptic-scale patterns of past atmospheric circulation over western North America (Manabe and Broccoli 1985; Kutzbach and Guetter 1986; Rind 1987). Although (1) the resolution of these

Offprint requests to: $\mathrm{S}$. Hostetler models is coarse (the NCAR Community Climate Model, CCMO, used by Kutzbach and Gutter has a $4.4^{\circ}$ latitude grid), (2) the boundary conditions (e.g., sea surface temperatures and the size and height of the ice sheet) in the modeling experiments were prescribed, and (3) the models can have deficiencies that may lead to misplacement of the simulated jet stream, these simulations all indicate that during the late Pleistocene the polar jet stream probably was split around the North American continental ice sheet. (The split in the jet stream appears to have been caused by the height and size of the ice sheet and associated changes in atmospheric heating and cooling that developed over the ice.) A connection between late Pleistocene change in atmospheric circulation and the hydrologic budgets of the closed Great Basin lake systems (Fig. 1) has been suggested by Antevs (1948), Benson and Thompson $(1987 \mathrm{a}, \mathrm{b})$, and Lao and Benson (1988). Those authors hypothesized that a southern displacement of the jet stream by the continental ice sheet may have led to wetter conditions in the Great Basin.

In this study we tested the hypothesis that change in the position of the polar jet stream was the primary cause of the last late Pleistocene rise and fall of the large Great Basin lake systems. We used a physically based lake model to simulate changes in lake temperature and evaporation that occurred in response to change in the lake surface energy balance and in a small set of atmospheric parameters. A sensitivity analysis of evaporation was done by using plausible late Pleistocene air temperature and cloud cover that was assumed to have accompanied displacement of the polar jet stream. The input data set used in the sensitivity analysis consisted of proxy indicators of air temperature and an analogue for cloud cover related to the present-day jet stream. Input data sets for the lake level simulations consisted of evaporation rates calculated in the sensitivity analysis and historical along with hypothetical rates of precipitation and streamflow. The simulated lake level trajectories are compared with the late Pleistocene chronology of Lake Lahontan (Benson et al., in press). 


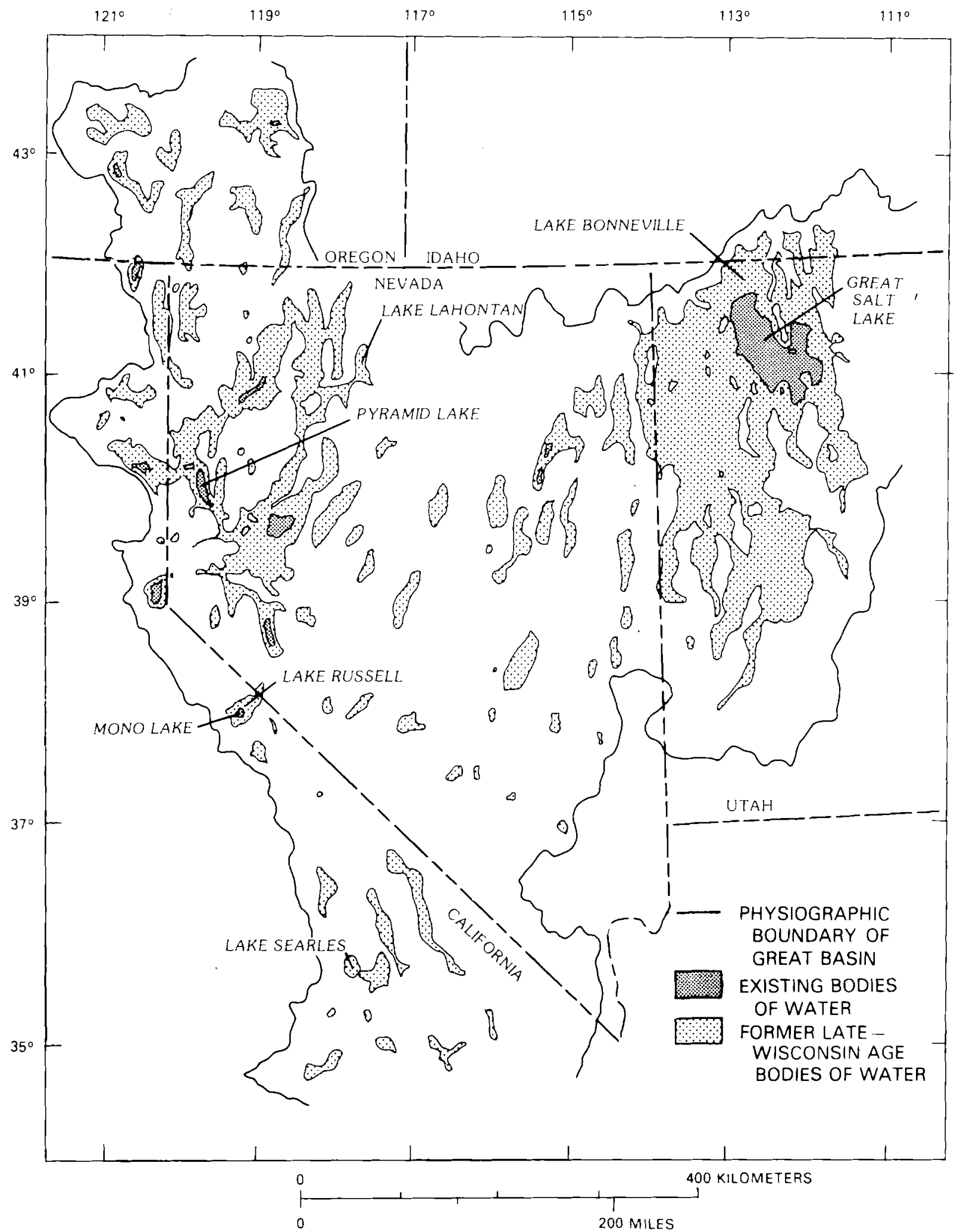

Fig. 1. Size and location of late Pleistocene lakes in the Great Basin

\section{Interpretation of AGCM jet-stream simulations}

The simulations of Kutzbach and Guetter (1986) indicate that $18-15 \mathrm{ka} \mathrm{BP}$, the mean winter (perpetual January) position of the core (maximum velocity) of the southern branch of the split jet stream (AGCM sigma level $0.5 ; \sim 500 \mathrm{mb}$ ) was at $\sim 33^{\circ} \mathrm{N}$ latitude (Fig. 2a). Between 15 and $12 \mathrm{ka} \mathrm{BP}$, the mean position of the winter jet stream core moved northward in response to a prescribed reduction in the size and height of the con- 


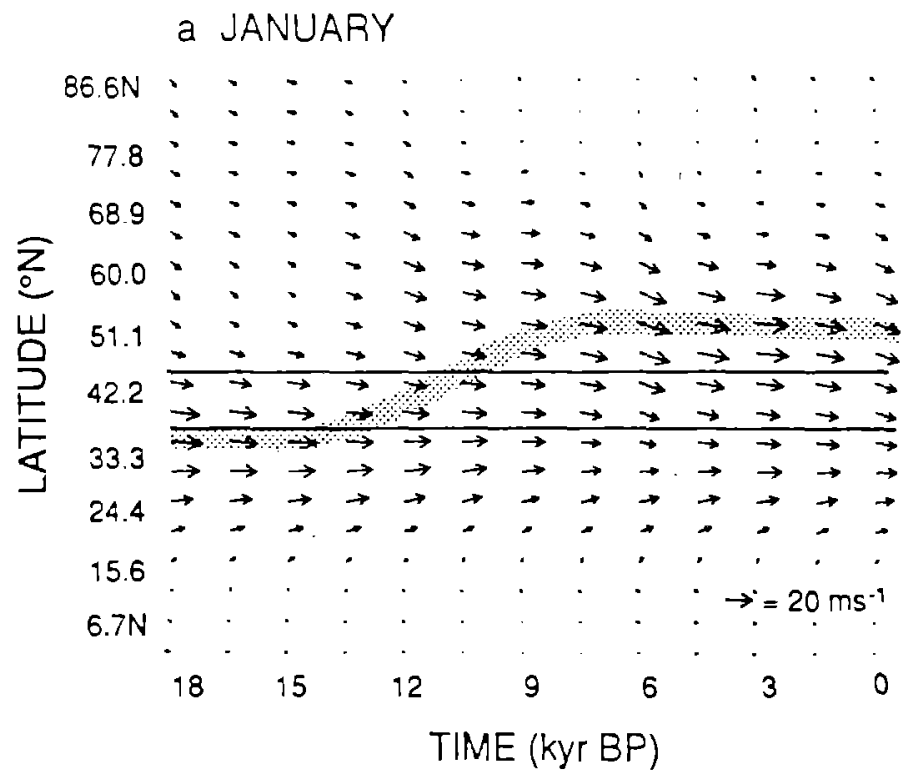

Fig. 2a, b. Latitude-time diagram of January (a) and July (b) mean upper level winds (at the 500-mb level) from 18 to $0 \mathrm{ka} \mathrm{BP}$ simulated by the NCAR Community Climate Model (CCMO). Values were simulated at 3-ka intervals from 18 to $0 \mathrm{ka} \mathrm{BP}$, values between the simulations were interpolated. Stippling indicates the latitude of the core of the southern branch of the jet stream (as

tinental ice sheet. Although no model simulation was carried out for $13.5 \mathrm{ka} \mathrm{BP}$, by interpolation the simulated mean position of the winter jet stream core moved northward to $\sim 37^{\circ} \mathrm{N}$. After $12 \mathrm{ka} \mathrm{BP}$, the ice sheet was small enough to allow the two branches of the winter jet stream to recombine and remain north of the Great Basin.

In the summer (perpetual July) of $18 \mathrm{ka} \mathrm{BP}$, the simulated mean position of the core of the southern branch of the summer jet stream was $\sim 45^{\circ} \mathrm{N}$ latitude (Fig. 2b). By interpolation, by $13.5 \mathrm{ka}$ BP the mean position of the jet stream core moved south of its $18 \mathrm{ka} \mathrm{BP}$ position. After $9 \mathrm{ka} \mathrm{BP}$, the simulated mean position of the summer jet stream was north of the Great Basin.

Today, along the west coast of North America, the seasonal location of the jet stream core varies by $\sim 16^{\circ}$ of latitude between the mean winter $\left(42^{\circ} \mathrm{N}\right)$ and summer $\left(58^{\circ} \mathrm{N}\right)$ positions (Bryson and Hare 1977). The simulations of Kutzbach and Guetter (1986) indicate that from 18 to $15 \mathrm{ka} \mathrm{BP}$, the latitudinal band most affected by season-to-season variations in the position of the jet stream was $\sim 12^{\circ}$ wide $\left(\sim 33-45^{\circ} \mathrm{N}\right)$. Between 15 and $13.5 \mathrm{ka} \mathrm{BP}$, the combined northward shift in winter and southward shift in summer of the jet stream could have led to a confined seasonal range over the northern Great Basin.

\section{Experimental hypotheses}

Spatial distributions of seasonal cloud cover, air temperature, and precipitation are strongly influenced by the position of the jet stream core (Riehl et al. 1954;

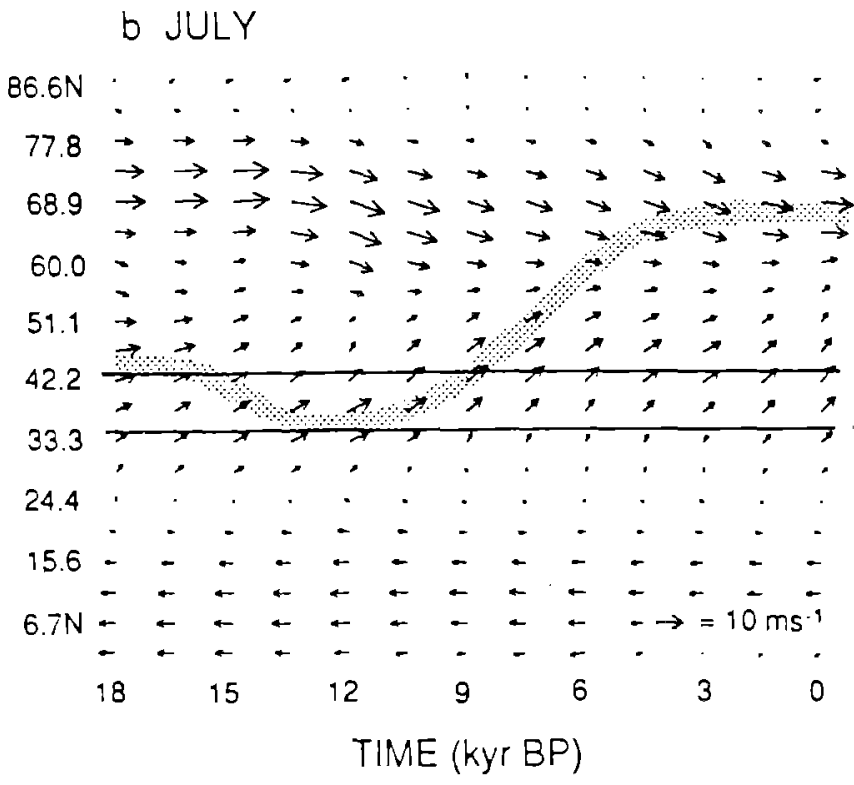

represented by the maximum vector wind). Data values are averages of three columns of western North America grid cells (at $127.5^{\circ}, 120.0^{\circ}$, and $112.5^{\circ} \mathrm{W}$ ). Solid horizontal lines indicate the approximate latitudinal extent of the Great Basin (data from Kutzbach and Guetter 1986)

Pyke 1972; Bryson and Hare 1977; Hare and Hay 1977). If, during the late Pleistocene, the climatic characteristics of the jet stream were similar to those of today, then the positioning of the jet stream over the Great Basin at that time should have led to relatively cooler and wetter conditions in that region.

The presence of cold, late Pleistocene air temperatures over the Great Basin has been previously hypothesized. Evidence in support of colder temperatures has been reported in studies of nivation features (Dohrenwend 1984) and pack rat middens (Thompson and Mead 1982; Thompson 1984). These studies suggest that during the late Pleistocene, Great Basin air temperatures were at least $5-7^{\circ} \mathrm{C}$ colder than today. Existence of a cold period also is supported by the presence of ice-rafted material in a 75-m core taken from the north shore of Pyramid Lake (L Benson and G Kukla, unpublished data), indicating that at least partial ice cover formed on Lake Lahontan during the Pleistocene. Ice never has been observed to form on Pyramid Lake during the historical past.

Chronologies of the Great Basin lake systems (Benson et al., in press) indicate that the late Pleistocene was wetter than today. Previous workers (e.g., Snyder and Langbein 1962; Mifflin and Wheat 1979) hypothesized that increased net basin supply (i.e., total water inputs minus outputs) was the result of increased rates of precipitation and decreased rates of evaporation. Benson (1981) demonstrated the potential importance of cloud cover and air/water temperature gradient on change in evaporation rate.

In this study it is suggested that (1) 20-15 ka BP, the entire Great Basin was within the latitudinal band affected by the season-to-season variation in the position 
of the jet stream, resulting in increased wetness throughout the Great Basin, (2) 15-13.5 ka BP, the latitudinal band affected by this season-to-season variation was located over the northern Great Basin, and (3) after $13.5 \mathrm{ka} \mathrm{BP}$, the latitudinal band affected by the seasonto-season variation in the position of the jet stream core was located north of the Great Basin. We suggest that the southern branch of the split jet stream led to extensive cloud cover over the Great Basin, particularly in summer. In contrast to previous workers who attributed low evaporation rates primarily to cold air temperatures (e.g., Snyder and Langbein 1962; Mifflin and Wheat 1979; Smith and Street-Perrott 1983), we further suggest that evaporation was energy limited; that is, low (summer) evaporation rates stemmed from a reduction of insolation by the presence of cloud cover.

As an analogue for 18-13.5 ka BP cloud cover, the historical cloud climatology from Prince George, British Columbia, Canada ( $53^{\circ} 53^{\prime} \mathrm{N}$ lat., $122^{\circ} 41^{\prime} \mathrm{W}$ long., $206 \mathrm{~m}$ alt.) was used. Prince George lies between the latitude of the present-day mean summer $\left(58^{\circ} \mathrm{N}\right)$ and winter $\left(42^{\circ} \mathrm{N}\right)$ positions of the jet stream core and thus is affected by the season-to-season variation in the position of the jet stream. Prince George also is located in an intermontane basin like the Great Basin. To the west of Prince George, the Coast Range mountains (maximum altitude $\sim 3700 \mathrm{~m}$ ) form an orographic barrier to precipitation from storms moving onshore from the northern Pacific Ocean, just as the Sierra Nevada mountains (maximum altitude $\sim 3800 \mathrm{~m}$ ) block Pacific precipitation from reaching the Great Basin.

\section{Thermal model description}

Evaporation is governed by processes in the atmospheric boundary layer that largely depend on the temperature contrast between the lake surface and the overlying air (Brutsaert 1982). Accurate simulations of lake surface temperature are prerequisite to obtaining accurate estimates of evaporation. In the absence of the flux of advected heat from streamflow discharge, the annual course of lake heat storage (and thus temperature) is primarily determined by the lake surface energy balance (SEB) as follows:

$\Delta Q_{S}=\left(1-\alpha_{S W}\right) K_{D}+\left(1-\alpha_{L W}\right) L_{D}-L_{U} \pm Q_{E} \pm Q_{H}$,

where $\Delta Q_{S}$ is change in lake heat storage, $\alpha_{S W}$ is the short-wave albedo of the lake surface, $K_{D}$ is global (direct + diffuse) short-wave radiation, $\alpha_{L W}$ is the longwave albedo of the lake surface, $L_{D}$ is long-wave radiation from the atmosphere, $L_{U}$ is long-wave radiation from the lake surface, $Q_{E}$ is the flux of latent heat, and $Q_{H}$ is the flux of sensible heat. (A plus sign indicates that the flow of energy is toward the lake surface.)

The one-dimensional thermal model used in this research simulates the major features of the thermal cycles of temperate lakes (surface temperature and temperature stratification) by accounting for the (vertical) physical processes that govern lake heating (imbalance in the SEB, absorption of penetrating solar radiation, turbulent mixing, and convection). The model simulates lake temperature (a measure of stored heat), evaporation, and components of the SEB $\left(L_{U}, Q_{E}\right.$, and $\left.Q_{H}\right)$ in response to an input data set consisting of radiation inputs $\left(K_{D}\right.$ and $\left.L_{D}\right)$, and meteorological parameters (air temperature, humidity, wind speed). Wind-driven turbulent mixing is simulated as eddy diffusion by the parameterization of Henderson-Sellers (1985). The model equation is written

$$
\begin{aligned}
\frac{\partial T}{\partial t} & =\frac{1}{A(z)} \frac{\partial}{\partial z}\left\{A(z)\left[\kappa_{m}+K(z, t)\right] \frac{\partial T}{\partial z}\right\} \\
& +\frac{1}{C} \frac{1}{A(z)} \frac{\partial A(z) \Phi}{\partial z},
\end{aligned}
$$

where $T$ is lake temperature, $t$ is time (here taken as one day), $A(z)$ is the area of the lake at depth $z, \kappa_{m}$ is molecular diffusivity, $K(z, t)$ is eddy diffusivity, $C$ is the heat capacity of water, and $\Phi$ is a heat source term representing the subsurface absorption of solar radiation. The first term on the right-hand side of Eq. 2 represents heat transfer by diffusion; the second term represents subsurface heating by penetrating short-wave radiation.

The SEB is included in the surface boundary conditions for Eq. 2:

$$
\begin{aligned}
& {\left[\kappa_{m}+K(z, t)\right] \frac{\partial T}{\partial z}} \\
& =\left(1-\alpha_{S W}\right) K_{D}+\left(1-\alpha_{L W}\right) L_{D}-L_{U} \pm Q_{E} \pm Q_{H} .
\end{aligned}
$$

We assume in this study that the lake water is insulated from the underlying sediments, which leads to the bottom boundary condition of $\left[\kappa_{m}+K(z, t)\right] \partial T / \partial z=0$. The initial condition is specified by selection of the temperature/depth profile at $t=0$.

Evaporation $E$ is computed in this application of the model by the bulk-transfer equation of Harbeck (1962):

$E=N U_{2}\left(e_{0}-e_{a}\right)$,

where the mass-transfer coefficient $N$ is a function of lake surface area, $U_{2}$ is the wind speed at $2 \mathrm{~m}, e_{0}$ is the saturation vapor pressure at the lake surface, and $e_{a}$ is the air vapor pressure of the overlying atmosphere. Harbeck's equation was derived from evaporation studies of arid region lakes in the western United States.

A numerical scheme is included in the model to simulate convective mixing that is caused by surface heat losses. A major advantage of this model in climate studies is that it can be applied without the need for lakespecific tuning of model parameters. A complete description of the model, model process equations, and model validation is presented in Hostetler (1987) and Hostetler and Bartlein (in press).

\section{Model validation}

During 1987-1988, the U.S. Geological Survey Arid Regions Climate Project collected meteorological and water temperature data at Pyramid Lake, Nevada, to ob- 


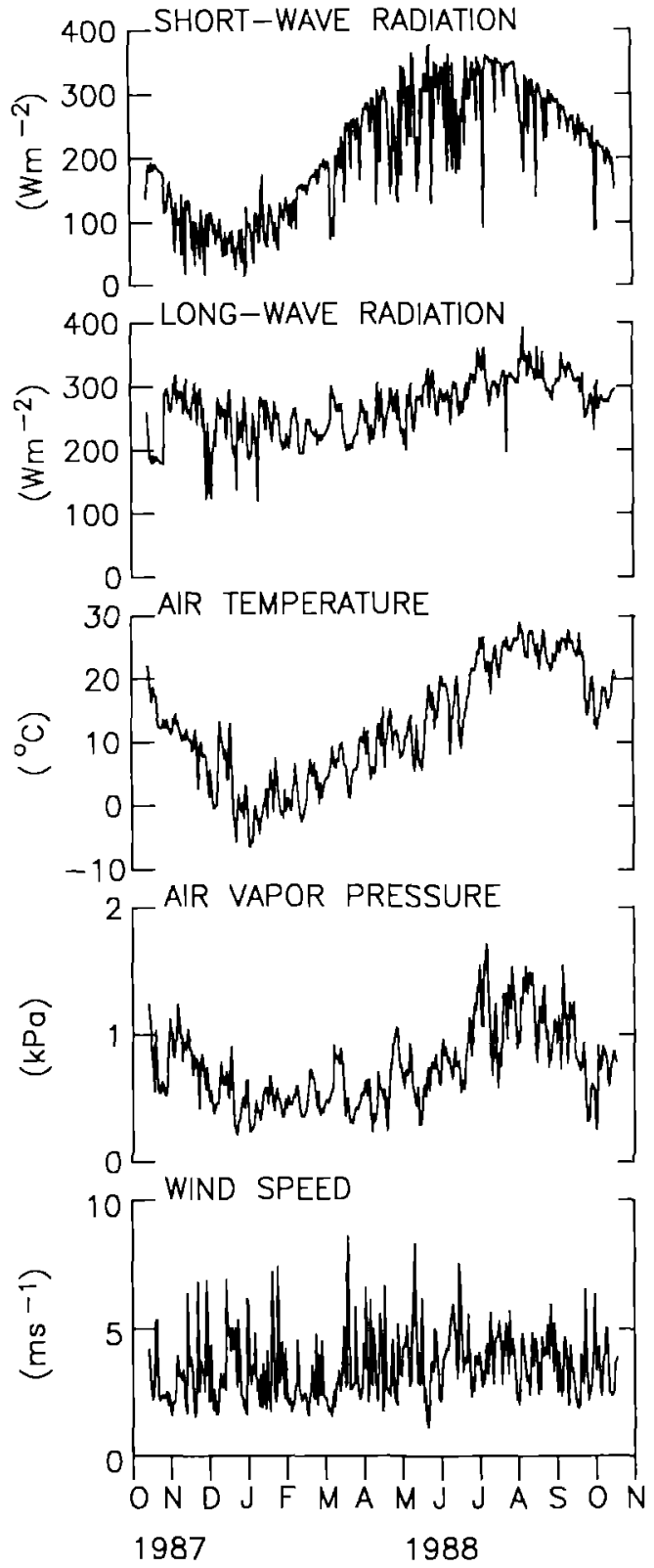

Fig. 3. Daily average meteorological data used as input for the model validation. The data were collected at Pyramid Lake, $\mathrm{Ne}$ vada, from 12 October 1987 thru 12 October 1988

tain a climatological data set with which to validate the thermal model and to establish a modern data set for use in our evaporation sensitivity analysis. Hourly measurements of short- and long-wave radiation, wind speed (and direction), air temperature, and relative humidity were made at four land-based meteorological stations adjacent to the lake. Simultaneous measurements of water temperature were made at four lake sites, using rafts outfitted with thermistor strings. Daily averages of the meteorological data (Fig. 3) were used as input to the model to obtain simulations of lake temperature and the rate of evaporation.

The lake temperatures simulated by the model agreed very well with observed temperatures (Figs. 4,

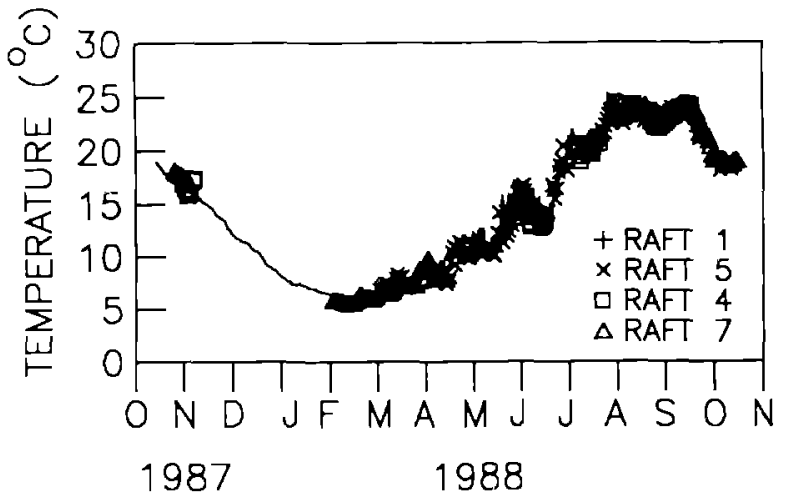

Fig. 4. Simulated 1987-1988 daily surface temperature of Pyramid Lake $(-)$ compared to temperatures recorded at four raft sites (symbols). The correlation coefficient $R^{2}$ between simulated and observed temperatures exceeded $0.94(p<0.01)$ for all raft sites

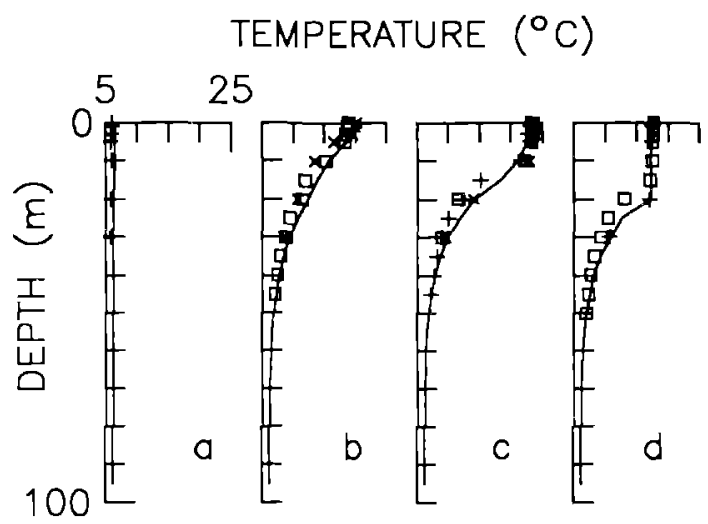

Fig. 5a-d. Selected comparisons between simulated (-) and observed (symbols) depth/temperature data for Pyramid Lake: a, 19 Feb 1988; b, 29 Jun 1988; c, 08 Aug 1988; d, 27 Oct 1988

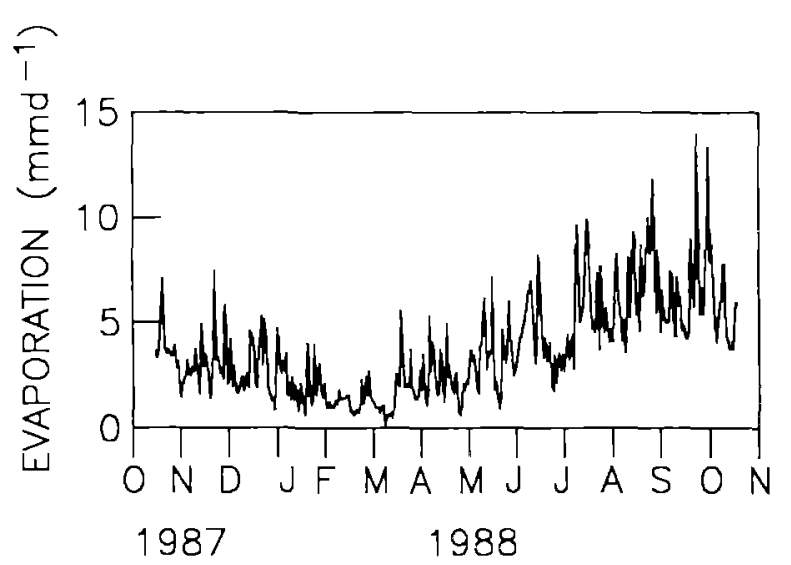

Fig. 6. Simulated 1987-1988 daily evaporation rates for Pyramid Lake. Annual total evaporation is $1311 \mathrm{~mm}$

5). The simulated annual evaporation rate of $1311 \mathrm{~mm}$ (Fig. 6) compared well with the historical range of $1.2 \pm 0.1 \mathrm{~m}$ reported by Harding (1965) and the historical rate of $1.25 \mathrm{~m}$ estimated by Milne (1987). 


\section{Thermal model process equations}

Three process equations were used to derive model input variables for our hypothesized changes in late Pleistocene climates. Air vapor pressure varies with air temperature and directly affects the evaporation rate simulated by the model (Eq. 4). The equation used to compute air vapor pressure as a function of air temperature was from Richards (1971):

$$
\begin{aligned}
e_{a}\left(T_{k}\right) & =R H\left[1 0 1 . 3 2 5 \operatorname { e x p } \left(13.3185 t_{k}-1.9760 t_{k}^{2}\right.\right. \\
& \left.\left.-0.6445 t_{k}^{3}-0.1299 t_{k}^{4}\right)\right]
\end{aligned}
$$

where $T_{k}$ is the air temperature in degrees Kelvin, $R H$ is the relative humidity, and $t_{k}=1-\left(373.15 / T_{k}\right)$.

Estimates of global short-wave and atmospheric long-wave radiation as functions of atmospheric composition and cloud cover can be obtained from a number of parameterizations (e.g., Kondrateyev 1969; Iqbal 1983). To assess the sensitivity of evaporation to large changes in seasonal cloud cover, relatively simple but sufficiently accurate approaches to estimating radiation were selected. Daily integrals of short-wave radiation were estimated with the equation of Prescott (1940):

$K_{D}=E X\left[a_{S W}+b_{S W}(1-C)\right]$,

where $E X$ is radiation at the top of the atmosphere, $a_{S W}=0.5$ and $b_{S W}=0.25$ are empirical constants, and $C$ is the portion of the sky (in tenths) obscured by cloud. $E X$ (Fig. 7) was computed by standard algorithms for insolation as a function of solar position (Iqbal 1983). The constants $a_{S W}$ and $b_{S W}$ in Eq. 6 have been shown to vary with location, time of year, and cloud type. The values of the constants used in our experiment are cited by Brutsaert (1982) as the averages from eleven studies. The correlation coefficient $R^{2}$ between observed shortwave radiation at Pyramid Lake (Fig. 3) and values estimated by Eq. 6 with observed cloud cover (Fig. 7) was 0.57 (at $p<0.05$ ). Only about nine months of observed estimates of cloud cover were available for 1987-1988. We attribute error in the simulated values to the simplicity of the Prescott relation and to errors in the estimates of sky cover at Pyramid Lake.

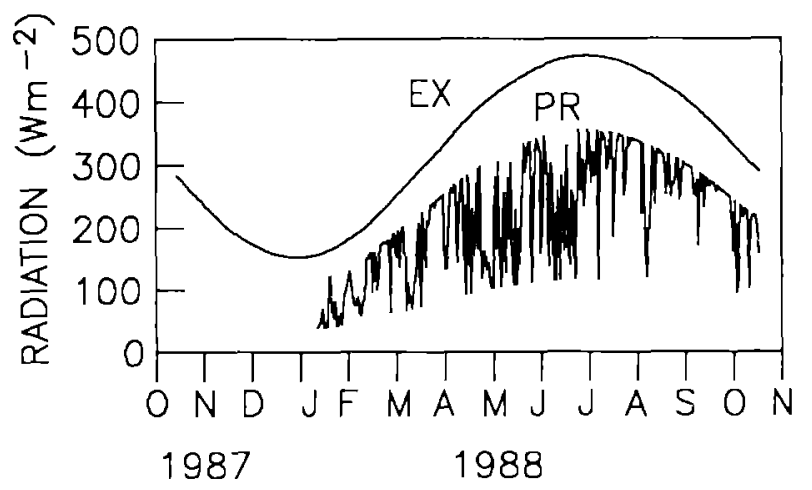

Fig. 7. Daily integrals of short-wave radiation: $E X$, radiation at the top of the atmosphere: $P R$, global short-wave radiation at the ground estimated with equation of Prescott (1940) using observed Pyramid Lake cloud-cover data

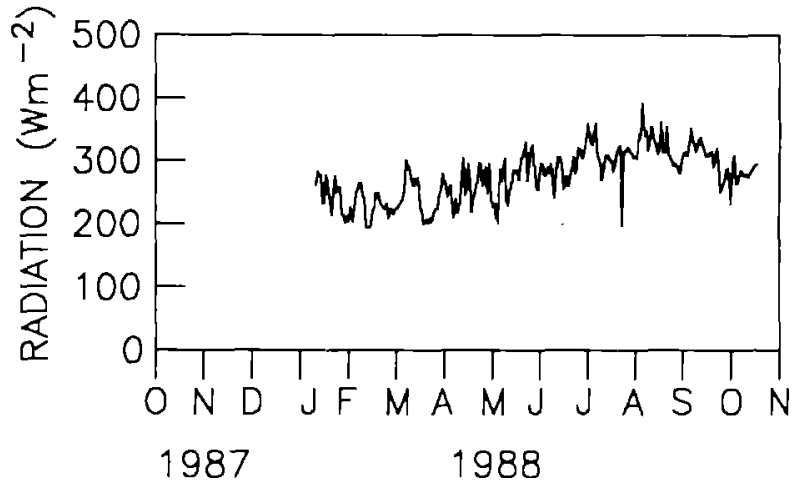

Fig. 8. Daily integrals of atmospheric long-wave radiation estimated using equation of Idso (1981) for atmospheric emissivity and observed Pyramid Lake cloud-cover data

Atmospheric long-wave radiation was estimated (Oke 1987) by

$L_{D}=\varepsilon \sigma T_{a}^{4}\left(1-a_{L W} C\right)$,

where $\varepsilon$ is atmospheric emissivity, $\sigma$ is the StephanBoltzmann constant, $T_{a}$ is air temperature, and $a_{L W}=0.5$ is an empirically derived constant. To estimate emissivity, we used the equation of Idso (1981):

$\varepsilon=0.70+5.95 \times 10^{-5} e_{\mathfrak{a}} \exp \left(1500 / T_{\mathfrak{a}}\right)$,

The long-wave radiation values estimated by Eqs. 7 and 8 (Fig. 8) compared well $\left(R^{2}=0.78, p<0.05\right)$ with observed values (Fig. 3). Note that atmospheric long-wave radiation is explicitly affected by changes in humidity and air temperature (Eq. 8).

\section{Lake level model}

Lake Lahontan can be considered a closed-basin lake because the net ground-water flux in the Lahontan Basin probably is insignificant compared to other components of the hydrologic budget (Everett and Rush 1967). For lake-level simulations, we used the standard equation that equates change in the level of a closedbasin lake to change in the water balance of the lake:

$d z=(P-E)+I / A(z)$,

where $d z$ is the change in lake surface elevation, $P$ is the rate of precipitation over the lake, and $I$ is the rate of streamflow discharge into the lake.

The Lahonton Basin contains seven subbasins (Benson and Mifflin 1985). As a lake in one subbasin rises above its sill level, water spills into an adjacent basin. When the water surface level of all the subbasins reaches an elevation of $1308 \mathrm{~m}$ the lake rises as a single water body. To preserve the integrated depth/area relation of the basin, while removing the effects of sills on the filling of the Lahontan Basin so that one lake thermal model could be used instead of a model for each subbasin, depth/area data for input to the model (Fig. 9) were derived by summing subbasin areas at $1-\mathrm{m}$ increments of elevation. 


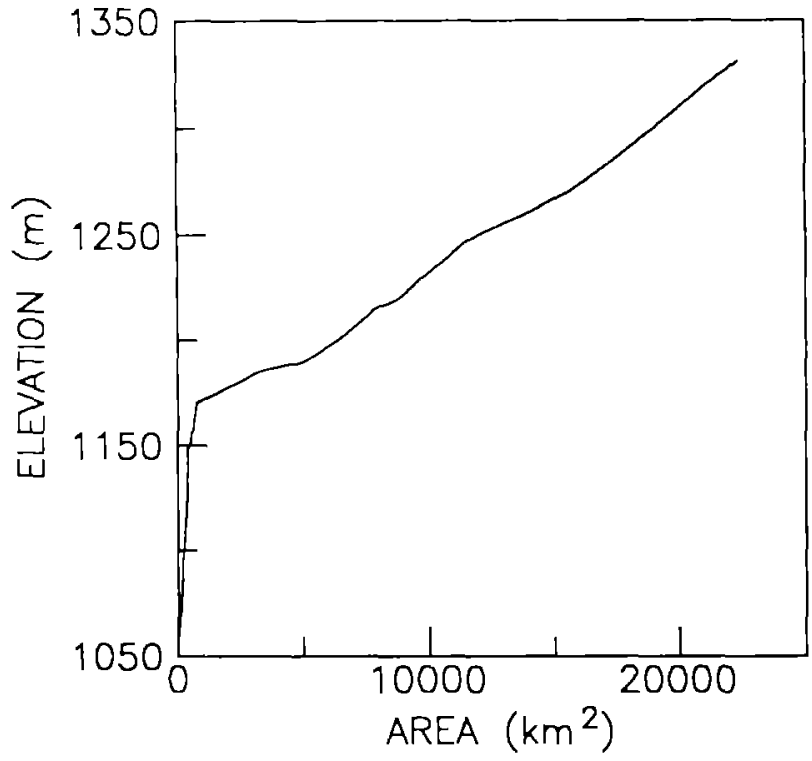

Fig. 9. Derived integrated depth-area data for the Lahontan Basin (Data from Benson and Mifflin 1985) is $\sim 53 \%$ greater than the mean annual value of cloud cover $(\sim 0.45)$ for Reno, Nevada (Fig. 10). The cloud cover value of 0.69 was used in Eq. 6 to compute daily integrals of short-wave radiation and in Eq. 7 to compute daily integrals of long-wave radiation (Fig. 11). With this cloud cover, the computed mean annual value of short-wave radiation was $125 \mathrm{~W} \mathrm{~m}^{-2}$, a value $\sim 43 \%$ lower than the observed mean annual value of 220 $\mathrm{W} \mathrm{m}^{-2}$. The largest reduction was in summer (Fig. 11). The mean annual value of computed long-wave radiation was $241 \mathrm{~W} \mathrm{~m}^{-2}$, a value $\sim 15 \%$ less than the observed mean annual value of $282 \mathrm{~W} \mathrm{~m}^{-2}$.

\section{Results}

The results of the evaporation sensitivity tests are summarized in Table 1. The initial condition for simulations 1-3 was the observed temperature profile from 12 October 1987. For simulations 4-6, the initial condition was specified by extrapolating the isothermal bottom temperature $\left(5.8^{\circ} \mathrm{C}\right)$ of the $100-\mathrm{m}$ lake to $277 \mathrm{~m}$. For sim-

Table 1. Results of evaporation sensitivity tests under different hypothesized climatic conditions (Ta, air temperature; AVP, air vapor pressure; C, cloud cover; S-W short-wave radiation; L-W, long-wave radiation)

\begin{tabular}{|c|c|c|c|c|c|c|c|}
\hline \multirow[t]{2}{*}{ SIM } & \multirow[t]{2}{*}{ Depth (m) } & \multirow[t]{2}{*}{ Input data } & \multicolumn{3}{|c|}{ Temperature $\left({ }^{\circ} \mathrm{C}\right)$} & \multicolumn{2}{|c|}{ Evaporation } \\
\hline & & & $\operatorname{Max}$ & Min & Mean & $\mathrm{mm}$ & $\% \operatorname{SIM} 1$ \\
\hline 2 & 100 & $\begin{array}{l}-7^{\circ} \mathrm{C} \mathrm{Ta} \\
\mathrm{AVP}(\mathrm{Ta})\end{array}$ & 22.8 & 5.7 & 13.3 & 1129 & 86 \\
\hline 3 & 100 & $\begin{array}{l}-7^{\circ} \text { C Ta } \\
\text { AVP (Ta) } \\
\text { C }=0.69 \\
\text { S-W (C) } \\
\text { L-W (C, Ta, AVP })\end{array}$ & 14.0 & 0.9 & 6.7 & 758 & 58 \\
\hline 4 & 277 & Present & 25.1 & 7.0 & 14.8 & 1304 & 99 \\
\hline 5 & 277 & As run 2 & 22.0 & 5.7 & 13.1 & 1135 & 88 \\
\hline 6 & 277 & As run 3 & 14.0 & 1.3 & 6.8 & 777 & 60 \\
\hline
\end{tabular}

\section{Evaporation sensitivity tests}

Six sensitivity tests (Table 1 ) were run with the thermal model to assess how a $7^{\circ} \mathrm{C}$ air temperature reduction and our hypothesized (analogue) increase in cloud cover related to the jet stream might have affected both the thermal regime and evaporation of Lake Lahontan. Input data for the model runs were derived by adjusting the observed 1987-1988 Pyramid Lake air temperature data directly and by estimating air vapor pressure and short- and long-wave radiation. The decrease in mean annual air temperature was distributed in the modern data set subtracting $7^{\circ} \mathrm{C}$ from daily observed values. Air vapor pressure was estimated by using Eq. 5 with the perturbed air temperature data and observed values of relative humidity.

A constant fractional cloud cover value of 0.69 (the mean annual cloud cover at Prince George is $0.69 \pm 0.05$, Hare and Hay 1977) was used. This value ulations $2-6$, the model was run for six years to eliminate any "memory" of the initial conditions and to obtain equilibrium values of simulated water temperature and evaporation consistent with the input data sets. The simulated thermal regime was nearly the same for both the 100-m (Pyramid Lake) and 277-m (Lake Lahontan) simulations; that is, the thermal regime within the first $100 \mathrm{~m}$ of the deeper lake was identical with the thermal regime of the $100-\mathrm{m}$ lake.

The $7^{\circ} \mathrm{C}$ air temperature reduction (simulations 2 and 4) resulted in a $1.3^{\circ} \mathrm{C}$ decrease (relative to simulation 1) in the mean annual water surface temperature and a $\sim 14 \%$ decrease in annual rate of evaporation in both the shallow- and deep-lake simulations. When the air temperature reduction was combined with the analogue jet stream cloud cover (simulations 3 and 6), the simulated mean annual temperature of the water surface was decreased by $7.8^{\circ} \mathrm{C}$, and the rate of evaporation was decreased by $\sim 42 \%$ to $758 \mathrm{~mm} \mathrm{a}^{-1}$. (The an- 


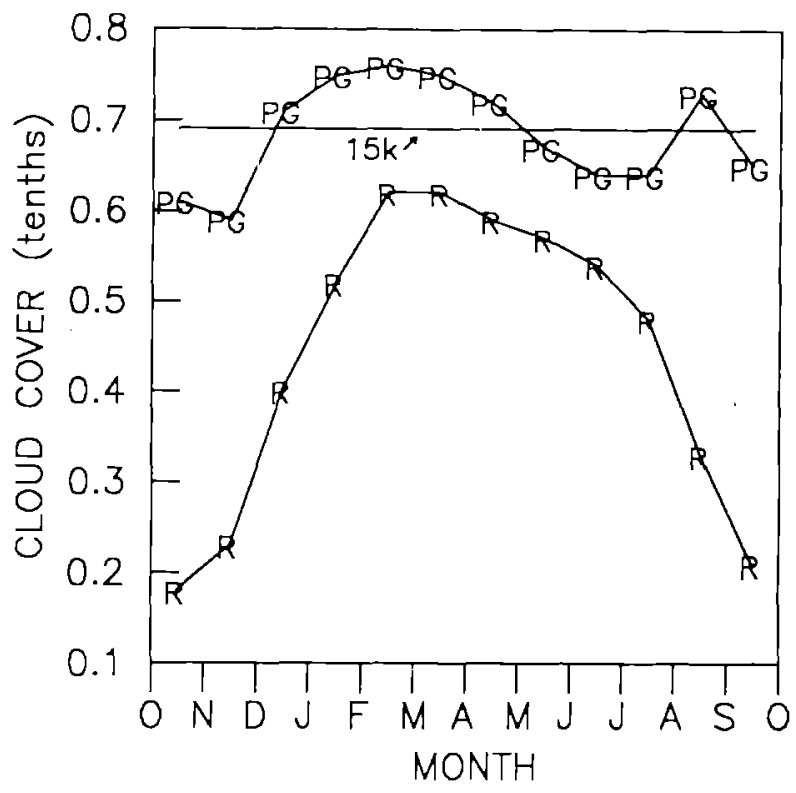

Fig. 10. Mean monthly cloud-cover data from Prince George, British Columbia, Canada $(P G)$, compared with Reno, Nevada $(R)$, and the 20-13.5 ka BP (15-ka) cloud cover assumed in this report (Prince George data from Hare and Hay 1977, and Reno data from Benson 1986)

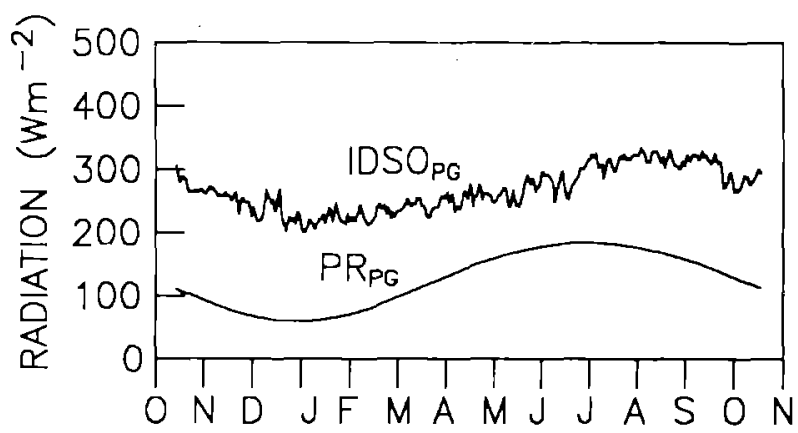

Fig. 11. Simulated daily integrals of short-wave $\left(P R_{P G}\right)$ and longwave $\left(I D S O_{P G}\right)$ radiation at the ground obtained by using a constant, mean annual cloud cover of 0.69

nual evaporation rate of $758 \mathrm{~mm} \mathrm{a}^{-1}$ from simulation 3 is comparable to the estimated rate of lake evaporation of $700 \mathrm{~mm} \mathrm{a}^{-1}$ for lakes around Prince George; Energy, Mines and Resources Canada 1974.) On a monthly basis, the highest reductions in evaporation rate occurred during summer and early fall (Fig. 12).

The minimum water surface temperature of $1.3^{\circ} \mathrm{C}$ (simulation 6) indicates that, under our hypothesized climate, ice cover could have formed, at least along the edges of Lake Lahontan during the winter. Edge ice would have been a sink to solar radiation during spring melting and thus would have suppressed evaporation more than the $\sim 42 \%$ reduction of simulation 3 . More extensive or persistent ice cover would have reduced lake evaporation even further.

Two other simulations, not shown in Table 1, were made to assess the impact on evaporation of a possible $3^{\circ} \mathrm{C}$ increase in mean annual air temperature during
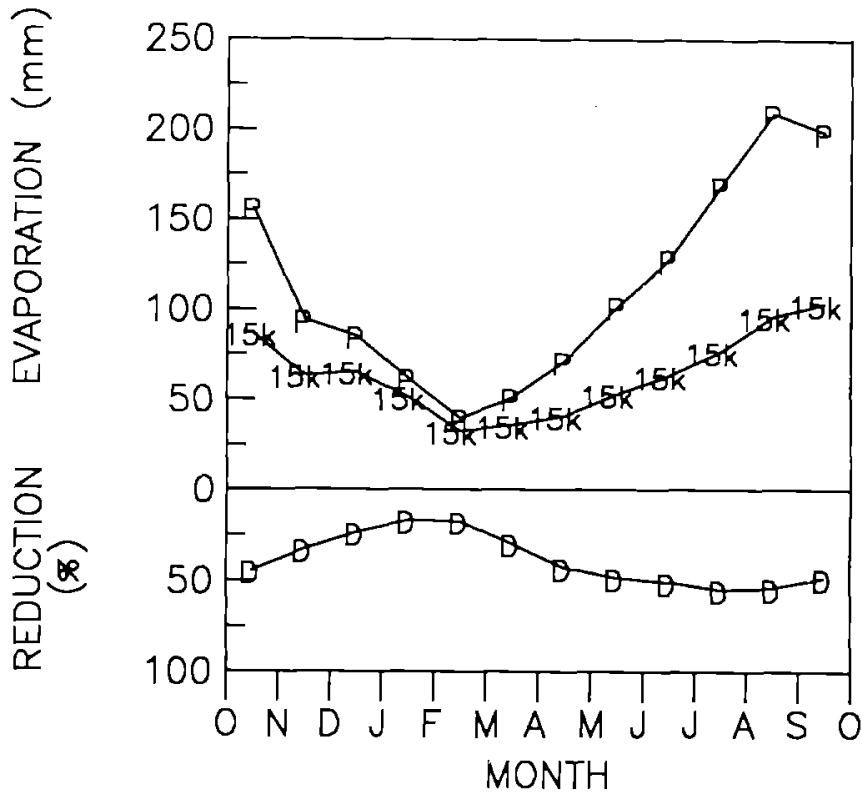

Fig. 12. Top. Simulated monthly evaporation rates from Pyramid Lake $(P)$ at present and Lake Lahontan for assumed $18-13.5 \mathrm{ka} \mathrm{BP}$ conditions (15 ka). Bottom. Differences between present and simulated paleoevaporation rates $(D)$

this period, and of the $13.5 \mathrm{ka} \mathrm{BP}$ change in solar radiation stemming from orbital variations. A $3^{\circ} \mathrm{C}$ increase in air temperature produced a $\sim 5 \%$ increase in the simulated annual evaporation rate (relative to simulation 2 ), and the $13.5 \mathrm{ka}$ BP radiation combined with the $3^{\circ} \mathrm{C}$ air temperature increase produced a $\sim 6 \%$ increase in evaporation rate.

\section{Lake level simulations}

Simulations of fluctuations in the size of Lake Lahontan originally were made with an interactive, thermal, lake-level model described by Hostetler (1987) and Hostetler and Bartlein (in press). In this model, thermal simulations were run on a daily time step and water balance (lake level) computations yielding change in lake level were run on a monthly time step. The possible dynamic influence of change in lake depth on the lake thermal regime (i.e., the linkage of the energy and hydrologic budgets) is thus accounted for in the interactive model. The model was used to assess the possible impact of cold streamflow discharge on lake temperature. The discharge temperature of $1^{\circ} \mathrm{C}$ was selected to represent the coldest water that might have come from melting montane glaciers and to maximize the potential effects of cold influent on the simulated thermal regime. The model was run until the simulated lake level reached equilibrium (i.e., until the difference between the surface elevation of the $n$th and $n$th +1 month was $<0.001 \mathrm{~m}$ ).

At the beginning of the simulation, the inflow of cold water lowered the mean annual temperature of the lake surface by about $1^{\circ} \mathrm{C}$ relative to a control simula- 
tion, in which advected heat was not included in the model. As the ratio of inflow volume to lake volume decreased, the effects of the cold influent diminished rapidly and became insignificant $\left(<0.01^{\circ} \mathrm{C}\right.$ decrease in mean annual surface temperature) by the time an equilibrium level was achieved. Based on this finding and on the agreement between the simulated thermal regimes and evaporation rates of the $100-\mathrm{m}$ and $277-\mathrm{m}$ lakes, we concluded that evaporation rates could be simulated with the thermal model alone, and that adequate simulation of the level of Lake Lahontan could be obtained by combining the simulated annual evaporation rates with hypothetical water inputs in the simple water balance model.

For three simulations of rising lake levels, the water balance model was initialized using the present-day level of Pyramid Lake (1154 m). For the simulation of the high stand of the lake, the water balance model was initialized at the $20-15 \mathrm{ka}$ BP level $(\sim 1260 \mathrm{~m})$. In the simulation of falling lake level, the model was initialized at the $13.5 \mathrm{ka}$ BP level $(1330 \mathrm{~m})$ of Lake Lahontan. An annual time step was used in all simulations, which were run until an equilibrium (defined above) lake depth was attained. The depth/area data used in the water balance model were taken from the integrated depth/area data illustrated in Fig. 9.

\section{Results}

Trajectory 1 of Fig. 13 is a control simulation that used as inputs the present mean annual rate of precipitation $\left(170 \mathrm{~mm} \mathrm{a}^{-1}\right)$, the total mean annual rate of streamflow discharge $\left(2.7 \mathrm{~km}^{3} \mathrm{a}^{-1}\right)$ into the Lahontan Basin, and

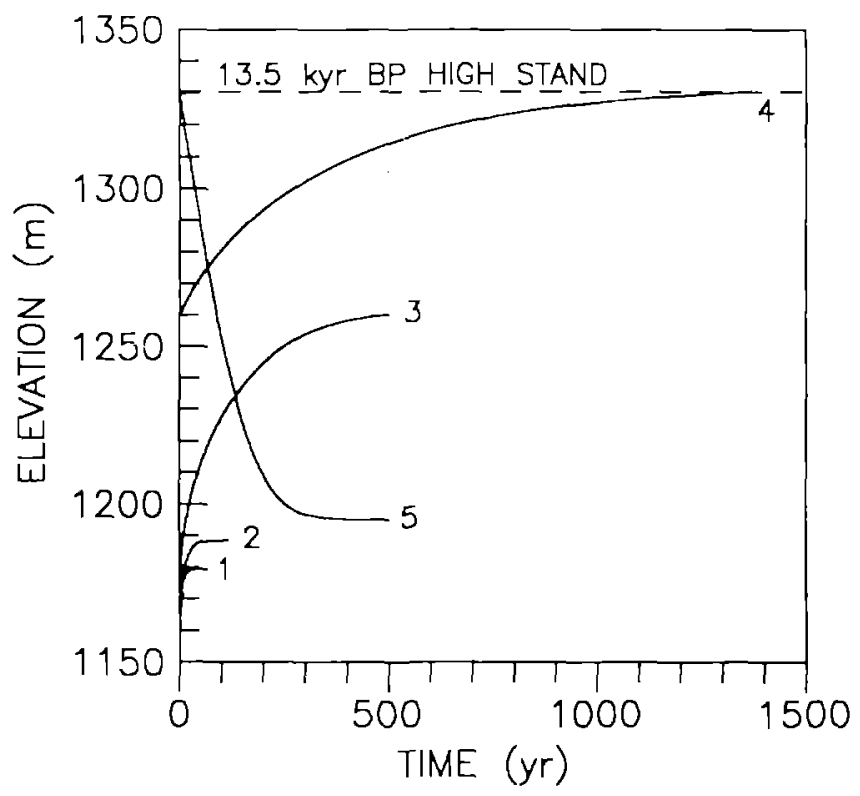

Fig. 13. Lake Lahontan lake-level simulations under different hydrologic balances (evaporation, precipitation, runoff) expressed as percent change in present mean annual rates. Trajectory $(T) 1$, $(0,0,0) ; T 2,(-42,0,0) ; T 3,(-42,76,140) ; T 4,(-42,76,280)$; $T 5,(0,76,140)$ the simulated $1987-1988$ evaporation rate $(1300 \mathrm{~mm}$ $\mathrm{a}^{-1}$ ) for Pyramid Lake. The use of present-day water inputs and an evaporation rate of $758 \mathrm{~mm} \mathrm{a}^{-1}$ did not alter the hydrologic balance significantly (trajectory 2 ). When the 1983 historical maximum rates of precipitation $\left(300 \mathrm{~mm} \mathrm{a}^{-1}\right)$ and streamflow discharge $\left(6.5 \mathrm{~km}^{3}\right.$ $\mathrm{a}^{-1}$ ) were combined with the maximum reduced evaporation rate (our estimated hydrologic budget $20-15 \mathrm{ka}$ $\mathrm{BP})$, the simulated lake attained an equilibrium level of $\sim 1260 \mathrm{~m}$ (trajectory 3 ). With the same rate of evaporation and the 1983 precipitation rate, a streamflow discharge rate of $10.3 \mathrm{~km}^{3} \mathrm{a}^{-1}$ (our estimated $13.5 \mathrm{ka}$ BP hydrologic budget) was sufficient to raise the level of Lake Lahontan to $\sim 1330 \mathrm{~m}$ in $\sim 1400$ years (trajectory 4). (Using a hydrologic budget of our lowest simulated evaporation rate, present-day precipitation from Prince George, i.e., $626 \mathrm{~mm} \mathrm{a}^{-1}$, and maximum historical discharge in the Lahontan Basin, Lake Lahontan rose above $1330 \mathrm{~m}$ in $<500$ years.) Benson and Thompson (1987b, p. 82) reported simulating the $1330-$ m-deep lake in $<100$ years with those authors' lake level program. A later simulation with hydrologic balance similar to simulation 4 indicated that a time span of $\sim 1200$ years actually was required for the lake to reach an equilibrium level of $1330 \mathrm{~m}$, a value in agreement with our calculation.

Trajectory 5 illustrates a simulation of lake level after a climate change that was associated with the northward migration of the polar jet stream $\sim 12.5 \mathrm{ka}$ BP. In this simulation, where the 1983 maximum historical rates of precipitation and discharge were combined with the present-day evaporation rate, the lake dropped $130 \mathrm{~m}$ from the initial level of $1330 \mathrm{~m}$ in $\sim 300$ years. The equilibrium response time ( $\sim 300$ years) for our simulation of the fall of Lake Lahontan was similar to the response time ( $\sim 250$ years) reported by Benson and Thompson (1987b, p. 83). The more rapid response reported by Benson and Thompson is the result of using present-day rates for all components of the hydrologic balance.

\section{Comparison with the Lake Lahontan chronology}

From 20 to $15 \mathrm{ka} \mathrm{BP}$, the level of Lake Lahontan was $\sim 1260 \mathrm{~m}$ (Fig. 14). A similar level was simulated (trajectory 3 ) in response to the hydrologic budget that was associated with our hypothesized $20-15$ ka BP climate conditions. This indicates the possibility that the lake could have been maintained at $\sim 1260 \mathrm{~m}$ under reduced summer evaporation and annual water inputs similar to 1983 (historical maximum) values. Between 15 and 13.5 $\mathrm{ka}$ BP, Lake Lahontan rose to a maximum level of $1330 \mathrm{~m}$. Under the hydrologic balance associated with our hypothesized climate for $15-13.5 \mathrm{ka} \mathrm{BP}$, the level of the lake rose from 1260 to $1330 \mathrm{~m}$ in $\sim 1400$ years (trajectory 4).

The chronology of Lake Lahontan indicates that lake levels lowered rapidly $\sim 13 \mathrm{ka}$ BP. Trajectory 5 represents a simulated fall in lake levels, using 1983 water inputs and present-day evaporation that have been 


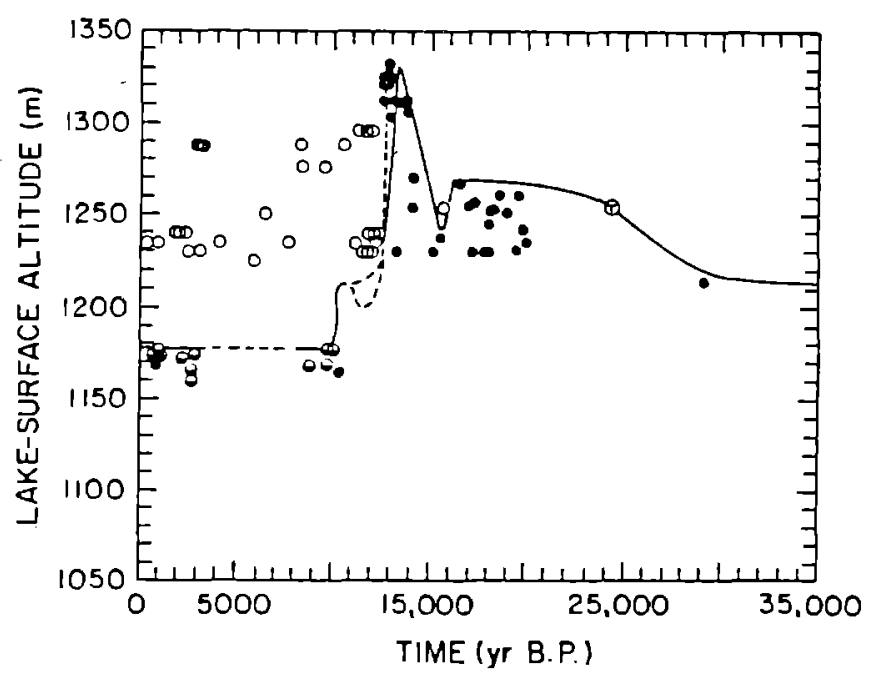

Fig. 14. Late Pleistocene lake-level chronology of Lake Lahontan (from Benson et al., in press). O Organic carbon deposited above lake level, Organic carbon deposited at or below lake level, Inorganic samples closely examined for contamination, $\mathcal{D}$ Tephra-based age of base of lake deposit in Black Rock Deposit

associated with movement of the jet stream north of the Lahontan Basin. The rapid lowering of Lake Lahontan, therefore, could have occurred under climatic and hydrologic conditions that have been observed within the historical record.

Benson and Thompson (1987b) suggested that the shape of the Lake Lahontan chronology indicates that 15-13 ka BP steplike climate changes occurred over the Great Basin as a result of rapid change in the mean position of the polar jet stream. The results of the dynamic lake level simulations do not refute that hypothesis.

\section{Summary}

We hypothesized that $20-15 \mathrm{ka} \mathrm{BP}$, season-to-season variation in the position of the southern branch of the split jet stream resulted in a cool and wet period throughout the Great Basin. We further suggested that between 15 and $13.5 \mathrm{ka} \mathrm{BP}$, the latitudinal range of the jet stream could have been narrowed and concentrated over the northern Great Basin. After $\sim 13 \mathrm{ka} \mathrm{BP}$, melting of the continental ice sheet allowed the split jet stream to recombine and to move north of the Great Basin causing increased aridity throughout the region. We also hypothesize that the period of increased wetness during the late Pleistocene was due to an increased precipitation rate and an energy-limited reduction in the evaporation rate that was caused by extensive summer cloud cover.

We tested these hypotheses using thermal evaporation and water balance models. The thermal evaporation model enabled the simulation of lake thermal structure and evaporation as functions of climatically determined changes in the atmospheric boundary layer and in the lake SEB (including heat storage). The ther- mal evaporation model was validated using a data set from Pyramid Lake, Nevada, and was applied in an investigation of the sensitivity of evaporation rate of Lake Lahontan to hypothesized late Pleistocene paleoclimate. The sensitivity tests indicated that a $7^{\circ} \mathrm{C}$ reduction in air temperature (derived from proxy climate indicators) would have lowered evaporation (relative to present) by only $\sim 14 \%$. A reduction of solar radiation resulting from the imposition of mean annual cloud cover of 0.69 , hypothesized to have been associated with a split in the polar jet stream, decreased lake evaporation by $\sim 42 \%$.

The lake level simulations indicate that (starting from the present-day level of Pyramid Lake) a hydrologic balance combining an evaporation rate of $758 \mathrm{~mm}$ $\mathrm{a}^{-1}$ and mean annual historical rates of precipitation $\left(170 \mathrm{~mm} \mathrm{a}^{-1}\right)$ and discharge $\left(2.7 \mathrm{~km}^{3} \mathrm{a}^{-1}\right)$ would result in a Lake Lahontan equilibrium level of $\sim 1180 \mathrm{~m}$ (the approximate Holocene level; Fig. 14) within 100 years. When water inputs were increased to historical maximum rates (our assumed $20-15 \mathrm{ka}$ BP values) the hydrologic balance of Lake Lahontan resulted in an equilibrium level of $\sim 1260 \mathrm{~m}$, which compared well with the Lake Lahontan chronology for 20-15.5 ka BP. The simulation of the high stand of the lake was accomplished using a 3.8-fold increase in mean annual discharge rate, combined with the minimum evaporation rate and the 1983 precipitation rate. Lowering of Lake Lahontan from the $13.5 \mathrm{ka}$ BP level to the Holocene level within $\sim 300$ years was simulated using 1983 maximum historical rates of precipitation and streamflow discharge, and the present-day evaporation rate. These simulations compare well with the Lake Lahontan chronology for 15-10 ka BP.

The evaporation model allowed us to estimate the impacts of climatic change on evaporation rates of Lake Lahontan. We still are unable to specify separately the temporal and spatial change of precipitation and discharge that supported the last high-stand cycle of the lake because, at present, no data are available to estimate explicitly the magnitude of either of these components of the hydrologic budget of Lake Lahontan. It is likely that the split of the jet stream during the late Pleistocene resulted in increased winter precipitation being delivered to the Great Basin by storms moving off the eastern Pacific Ocean. Benson and Thompson (1987a) have suggested that the regional climate of the Great Basin might have been influenced by feedback between the atmosphere and Lake Lahontan and Lake Bonneville. Work is now in progress to investigate lake/atmosphere feedback by coupling the lake model presented in this report with a limited-area model of regional climate.

Acknowledgements. This work was done while S Hostetler held a National Research Council-U.S. Geological Survey Research Associateship. Funding for this research also was provided by the National Research Program of the U.S. Geological Survey. We thank PJ Bartlein, JE Kutzbach, and RS Thompson for their valuable reviews of the manuscript. We also thank PJ Behling, Center for Climatic Research, University of Wisconsin, Madison, for providing the data for Fig. 2. 


\section{References}

Antevs E (1948) The Great Basin, with emphasis on glacial and post-glacial times; climatic changes and pre-white man. Bull Univ Utah Biolog Ser 19:168-191

Benson LV (1981) Paleoclimatic significance of lake-level fluctuations in the Lahontan Basin. Quat Res 16:390-403

Benson LV (1986) The sensitivity of evaporation rate to climate change - results of an energy-balance approach. US Geol Surv Water-Res Invest Report 86-4148

Benson LV, Mifflin MD (1985) Reconnaissance bathymetry of basins occupied by Pleistocene Lake Lahontan, Nevada and California. US Geol Surv Water-Resourc Inves Rep 85-4262. 14 $\mathrm{pp}$

Benson LV, Thompson RS (1987a) The physical record of lakes in the Great Basin. In: Ruddiman WF, Wright HE Jr (eds) North America and adjacent oceans during the last deglaciation. Geol Soc Am, pp 241-260

Benson LV, Thompson RS (1987b) Lake-level variation in the Lahontan Basin for the Past 50000 years. Quat Res 28:69-85

Benson LV, Curry DR, Dorn RI, Lajoie KR, Oviatt CG, Robinson SW, Smith GI, Stine S, Thompson RS (1990) Variation in sizes of four Great Basin lake systems during the past 35000 years. Paleogeog Paleoclim Paleoecol (in press)

Brutsaert W (1982) Evaporation into the Atmosphere. Reidel, Dordrecht, $299 \mathrm{pp}$

Bryson RA, Hare HK (1977) The climates of North America. In: Bryson RA, Hare HK (eds) Climates of North America, vol 11 of Landsberg, HE (ed) World survey of climatology. Elsevier, New York, pp 1-47

Dohrenwend JC (1984) Nivation landforms in the western Great Basin and their paleoclimatic significance. Quat Res 19:231 324

Energy, Mines and Resources Canada (1974) The National Atlas of Canada. McMillian, Toronto, $254 \mathrm{pp}$

Everett DE, Rush FE (1967) A brief appraisal of the Walker Lake area, Mineral, Lyon, and Churchill Counties, Nevada. US Geol Surv Water Resourc Reconn Ser Rep 40, 41 pp

Harding ST (1965) Recent variations in the water supply of the western Great Basin. Univ Calif Arch Ser Report 16, 226 pp

Harbeck GE Jr (1962) A practical field technique for measuring reservoir evaporation utilizing mass-transfer theory. US Geol Surv Prof Pap 272-E

Hare FK, Hay JE (1977) Climates of Canada and Alaska. In: Bryson RA, and Hare HK (eds) Climates of North America, vol 11 of Landsberg HE (ed) World survey of climatology. Elsevier, New York, pp 49-192

Henderson-Sellers B (1985) New formulation of eddy diffusion thermocline models. Appl Math Modelling 9:441-446

Hostetler S (1987) Simulation of lake evaporation with an energy balance-eddy diffusion model of lake temperature: model development and validation, and application to lake-level variations at Harney-Malheur Lake, Oregon. PhD Thesis, University of Oregon, Eugene, Oregon
Hostetler S, Bartlein PJ (1990) Simulation of lake evaporation with application to modeling lake-level variations at HarneyMalheur Lake, Oregon. Water Resour Res (in press)

Idso SB (1981) A set of equations for full spectrum and 8-14 $\mu \mathrm{m}$ and $10.5-12.5 \mu \mathrm{m}$ thermal radiation from cloudless skies. Water Resour Res 74:295-304

Iqbal M (1983) An introduction to solar radiation. Academic Press, Toronto, $390 \mathrm{pp}$

Kondrateyev J (1969) Radiation in the atmosphere. Academic Press, New York, $912 \mathrm{pp}$

Kutzbach JE, Guetter PJ (1986) The influences of changing orbital parameters and surface boundary conditions on climate simulations for the past 18000 years. J Atmos Sci 43:17261759

Lao Y, Benson LV (1988) Uranium-series age estimates and paleoclimatic significance of Pleistocene tufas from the Lahontan basin, California and Nevada. Quat Res 30:165-176

Manabe S, Broccoli AJ (1985) The influence of continental ice sheets on the climate of an ice age. Ann Glaciol 5:2167-2190

Mifflin MD, Wheat MM (1979) Pluvial lakes and estimated pluvial climates of Nevada. Nev Bur Mines Geol Bull 94, 57 pp

Milne W (1987) A comparison of reconstructed lake-level records since the mid-1800's of some Great Basin Lakes. MS Thesis, Colorado School of Mines, Golden, Colorado

Oke TR (1987) Boundary layer climates, 2nd edn. Methuen, London, $435 \mathrm{pp}$

Prescott JA (1940) Evaporation from a water surface in relation to solar radiation. Trans R Soc South Aust 64:114-125

Pyke CB (1972) Some meteorological aspects of the seasonal distribution of precipitation in the western United States and Baja California. University of California Water Resources Center, Contribution No 139

Richards JM (1971) Simple expression for the saturation vapor pressure of water in the range $-50^{\circ}$ to $140^{\circ}$. Br J Appl Phys 4:L15-L18

Riehl H, Alaka M, Jordan CL, Renard RJ (1954) The jet stream. Meteorol Monogr 2:23-47

Rind D (1987) Components of Ice Age circulation. J Geophys Res 92(D4): 4241-4281

Smith GI, Street-Perrott FA (1983) Pluvial lakes of the Western United States. In: Wright HE (ed) Late Quaternary environments of the United States. In: Porter SC (ed) The Late Pleistocene, vol 1. University Minn Press, Minneapolis, pp 190 211

Snyder CT, Langbein WG (1962) The Pleistocene lake in Spring Valley, Nevada and its climatic implications. J Geophys Res 67:2385-2394

Thompson RS (1984) Late Pleistocene and Holocene environments in the Great Basin. PhD Thesis, University of Arizona, Tucson, Arizona

Thompson RS, Mead JI (1982) Late Quaternary environments and biogeography in the Great Basin. Quat Res 25:39-55 